\title{
Hubungan Persepsi terhadap Lingkungan Kerja dengan Kepuasan Kerja yang Dimoderasi Motivasi Kerja pada Wiraniaga Ramayana Department Store Denpasar
}

\author{
Ivan Prasetya Winawan Made dan Supriyadi \\ Program Studi Psikologi, Fakultas Kedokteran, Universitas Udayana \\ Ivan_titan@yahoo.com
}

Abstrak

Kepuasan kerja karyawan merupakan perkiraan individu terhadap pekerjaan atau pengalaman positif pada diri individu. Perkiraan tersebut adalah hasil persepsi. Penting untuk menimbulkan persepsi yang positif dalam situasi yang terjadi di perusahaan terhadap karyawannya. Salah satu yang menjadi perhatian dalam upaya menciptakan persepsi yang baik pada karyawan adalah lingkungan kerja. Adanya lingkungan kerja yang buruk, akan menimbulkan persepsi buruk pada karyawan sehingga mereka akan merasa stress dan tidak nyaman saat bekerja, sehingga akan memengaruhi motivasi kerja pada karyawan. Hal tersebut akan berakibat negatif pada kredibilitas perusahaan. Ramayana adalah salah satunya, karena konsumen biasanya memandang kualitas perusahaan retail pada pelayanan oleh wiraniaganya.

Tujuan penelitian ini adalah untuk mengetahui apakah terdapat hubungan antara persepsi terhadap lingkungan kerja dengan kepuasan kerja wiraniaga Ramayana Department Store yang dimoderasi oleh motivasi kerja. Jumlah subjek pada penelitian ini berjumlah 46 orang dengan kriteria laki - laki dan perempuan yang bekerja sebagai wiraniaga dengan pengalaman kerja dalam ruangan selama minimal satu tahun di salah satu perusahaan retail di Denpasar yaitu Ramayana. Metode sampling yang digunakan adalah cluster sampling. Hasil data penelitian dianalisa dengan menggunakan Moderated Regression Analysis (MRA) dengan bantuan program IBM SPSS Statistics 20 for windows. Hasil yang diperoleh membuktikan bahwa motivasi kerja merupakan variabel moderator semu yang berinteraksi dengan persepsi terhadap lingkungan kerja sehingga dapat memberikan pengaruh terhadap kepuasan kerja. Hal tersebut dibuktikan melalui koefisien probabilitas yang tidak siginifikan pada uji signifikansi parameter individualnya, namun didapatkan koefisien yang signifikan pada uji signifikansi simultan.

Kata Kunci: Lingkungan Kerja, Kepuasan Kerja, Motivasi Kerja, Wiraniaga

\begin{abstract}
Employee's job satisfaction is an estimation of the job itself and positive experiences obtained by individuals. This estimation is the result of perception. It is important to make positive perception on the job situations for the employees. One to be concerned for the improvement of good perception is the work environment. With bad work environment, negative perception will appear in the employees, therefore making them feel stressed and uncomfortable at workplace. This will affect work motivation of the employees. These events will drop the credibility of the company. Ramayana is one of them, because consumer often view the quality of a retail company mainly on service by the salesperson.

The purpose of this research is to find out whether there is a correlation between perceptions of work environment moderated by work motivation, to job satisfaction of Ramayana Department Store salesperson. Subject involved in this research is 46 male and female salesperson with minimum one year indoor work experience on one of retail companies in Denpasar which is Ramayana. Sampling method used is cluster sampling. Data analyzed using Moderated Regression Analysis (MRA) with IBM SPSS Statistics 20 for windows program.

Result indicated that work motivation is a quasi-moderator variable which interact with perception to work environment and together affect job satisfaction. This result was proven by insignificant probability coefficient on individual parameter significance test, but the result of simultaneous significance test is significant.
\end{abstract}

Keywords: Work Environment, Job Satisfaction, Work Motivation, Salesperson 


\section{P. W. MADE \& SUPRIYADI}

\section{LATAR BELAKANG}

Dewasa ini, dalam menghadapi persaingan yang ketat antar perusahaan pada era globalisasi perusahaan dituntut berkembang dengan cepat dan mendapat hasil yang maksimal. Salah satu perusahaan yang terus berkembang adalah perusahaan ritel. Menurut Ashara (2015) dalam artikelnya, industri ritel Indonesia masih terus berkembang di tahun 2016 dan 2017, walaupun sebelumnya pada tahun 2015 keadaan ekonomi sempat melambat. Penyebab industri ritel dapat terus berkembang di Indonesia adalah keadaan demografi Indonesia, meningkatnya masyarakat kelas menengah dan perubahan gaya hidup, serta konsep wirausaha yang saat ini sedang berkembang pesat di masyarakat Indonesia. Industri ritel juga berkontribusi dalam mengurangi angka pengangguran di Indonesia karena industri ini mampu memberikan kontribusi positif terhadap kemajuan perekonomian skala lokal dan nasional.

Berdasarkan data dari BPPTSP \& PM (Badan Penyelenggara Pelayanan Terpadu Satu Pintu dan Penanaman Modal) Kota Denpasar, terdapat 47 perusahaan maupun perseorangan yang membuka toko modern di kota Denpasar. Data tersebut mencatat semua perijinan usaha toko modern terkait hingga tanggal 19 Juni 2017. Ini membuktikan bahwa usaha ritel juga mengalami perkembangan di Bali. Salah satu jenis dari peritel adalah department store, yang menawarkan berbagai macam lini produk dengan mutu pilihan.

Toko serba ada atau department store termasuk dalam kategori pengecer toko atau store retailing. Department store yang ideal memberikan kenyamanan berbelanja kepada konsumennya. Department store atau dalam bahasa Indonesianya yaitu toko serba termasuk dalam pengecer toko atau store retailing. Department store memiliki beberapa lini produk seperti pakaian, hiasan rumah dan alat rumah tangga yang masing-masing dioperasikan sebagai departemen yang terpisah oleh spesialis pembelian atau merchandiser (Kotler, 1994). Menurut Duncan (1951) Aktivitas perhitungan, periklanan, personil dan cicilan di Department store dipusatkan sehingga tidak memerlukan perhatian langsung dari orang yang melakukan proses penjualan dan pembelian. Menurut Lewinson (1989) yang membedakan Department store adalah struktur organisasinya, yang secara spesifik adalah derajat tinggi dari "departementalisasi". Pembagian pembelian berdasarkan departemennya dibagi menjadi departemen "keras" dan "lunak". Pembagian tersebut menyebabkan pembeli dapat fokus mencari barang dengan ragam pilihan yang terbatas sehingga mendapat produk terbaik.

Department store mewah di Jakarta bernama Galeries Lafayette mengedepankan konsep gerai yang unik, menyuguhkan beragam variasi musik, dan desain dinding disesuaikan dengan tema produk yang dipamerkan untuk memberikan suasana berbelanja yang seru kepada konsumen (Rema, 2013). Salah satu perusahaan ritel dengan Department store yang terus berkembang adalah PT. Ramayana Lestari Sentosa. Terhitung pada tahun 2017, Ramayana telah melakukan ekspansi dengan membuka empat gerai baru.
Jumlah seluruh gerai Ramayana terhitung hingga tahun 2017 adalah 116 gerai yang merupakan Department Store sekaligus supermarket (Dwijayanto, 2017).

PT. Ramayana Lestari Sentosa, Tbk adalah perusahaan yang bergerak dalam bisnis jaringan ritel di Indonesia. Pendiri perusahaan Ramayana adalah pasangan suami istri bernama Paulus Tumewu dan Tan Lee Chuan. Bapak Paulus Tumewu mengawali usaha ritelnya dengan mendirikan sebuah toko bernama Ramayana Fashion Store yang khusus menjual pakaian dan kain di Jalan Sabang pada tahun 1978. Ramayana menjadi jaringan ritel pada tahun 1989 yang memiliki 13 cabang dan mempekerjakan 2500 karyawan. Variasi produk yang dijual juga menjadi lebih luas seperti peralatan rumah tangga, mainan, dan alat kantor. Ramayana mengedepankan produk dengan harga terjangkau dan pelayanan bersahabat serta penuh perhatian terhadap konsumennya (Ramayana, 2017).

PT. Ramayana Lestari Sentosa, Tbk membuka cabang di Bali pada tahun 1997. Ramayana Department Store Denpasar merupakan cabang pertama yang didirikan di luar pulau Jawa. Menyusul cabang yang terletak di J1. Diponegoro, Ramayana kembali membuka cabang baru di Jalan Raya Sesetan dan Jl. P.B. Sudirman. Luas keseluruhan dari gedung hingga areal parkir Ramayana Department Store Denpasar mencapai 17.000 m2. Sampai saat ini, Ramayana Department Store Denpasar telah mempekerjakan karyawan sebanyak 268 orang dengan tambahan 340 orang wiraniaga yang memiliki ikatan kerja dengan vendor dari luar perusahaan. Gedung Department Store tersebut terdiri dari beberapa tingkat yaitu lantai dasar, lantai pertama, kedua, dan terakhir ketiga yang merupakan lantai teratas.

Awalnya Ramayana Department Store Denpasar dikepalai oleh Bapak Hermanto selaku regional manager, namun hingga saat ini telah mengalami tiga kali proses transformasi. Transformasi yang terakhir terjadi adalah pada bulan februari 2017 dan telah memberikan perubahan berupa peningkatan kesejahteraan karyawan dan peremajaan terhadap gedung Department Store. Regional manager (manajer daerah) yang mengepalai manajemen Ramayana Denpasar saat ini bernama Bapak I Gusti Bagus Ari Swarsana. Sistem manajemen teratas adalah koordinator manajer daerah yang disusul oleh manajer daerah, manajer toko, manajer asisten, supervisor, kepala counter dan karyawan. Koordinator manajer daerah tidak ditempatkan tetap di cabang perusahaan, karena itu manajer daerah yang memiliki posisi teratas di Ramayana Denpasar.

Ramayana Department Store Denpasar pernah meraih penghargaan best of the best in Indonesia pada tahun 2016. Penghargaan ini diberikan berdasarkan penilaian terhadap efisiensi biaya, omset penjualan, dan pencapaian serta pertumbuhan grup tiap tahunnya. Ramayana Department Store Denpasar mengunggulkan produk fashion yang ditawarkan kepada pelanggannya, walaupun memiliki supermarket di dalamnya. Transformasi yang dilakukan semenjak berdiri telah meningkatkan image perusahaan. Image yang dimaksud adalah customer yang awalnya berasal dari kelas menengah kebawah telah beranjak ke kelas menengah ke atas. 
Berdasarkan studi pendahuluan yang telah dilakukan peneliti, pihak manajemen Ramayana mengungkapkan telah memaksimalkan lingkungan kerja karyawannya. Disamping itu bagian supervisi juga meminta feedback dari karyawan dan wiraniaga sehingga dilibatkan dalam komunikasi dua arah, namun salah satu wiraniaga yang diwawancarai peneliti mengungkapkan bahwa masih terdapat kekurangan pada lingkungan kerjanya. Kekurangan ini antara lain adalah suhu yang panas, aroma toilet yang kurang sedap, dan suara bising yang terdengar setiap event berlangsung di dalam Department Store.

Menurut K sebagai salah satu wiraniaga yang bekerja di Ramayana Department Store, suhu panas disebabkan oleh masalah pada AC (Air Conditioner) sentral di tempatnya beroperasi. Menanggapi masalah ini, A selaku pihak manajemen Ramayana menyatakan bahwa penggunaan pendingin atau $\mathrm{AC}$ di tempat $\mathrm{K}$ beroperasi yaitu di lantai teratas memang disesuaikan dengan jumlah pengunjung yang ada di dalam gedung. Apabila pengunjung terlihat ramai, maka suhu akan didinginkan, sebaliknya jika pengunjung terlihat sepi pendingin di lantai teratas akan dimatikan sehingga terkadang terasa panas. Penyesuaian suhu ini diterapkan terkait dengan efisiensi biaya karena terjadi sedikit penurunan omset.

Aroma yang kurang sedap dari toilet yang berada pada lantai teratas juga menuai kritikan. $\mathrm{K}$ mengutarakan bahwa pelanggan yang berbelanja di lantai teratas sempat memberikan kritik terkait masalah toilet. A selaku pihak manajemen mengungkapkan bahwa memang di toilet pada lantai teratas tersebut sempat tersumbat, sehingga aroma yang kurang sedap dapat terhirup hingga ke luar toilet. Masalah tersebut terjadi karena masih diadakan renovasi di areal tersebut, akan tetapi saat ini toilet sudah diperbaiki sehingga tidak menimbulkan aroma kurang sedap seperti sebelumnya.

Suara bising juga sering terdengar oleh K saat bekerja. Suara ini disebabkan oleh pengumuman promosi yang dipersepsikan berisik. Menurut K, pelanggan juga sudah memberikan masukan kepada pihak manajemen terkait suara bising tersebut. Berdasarkan tanggapan A selaku pihak manajemen, suara bising yang dimaksud adalah pengumuman promosi yang dinamakan time service. Promosi ini memang menyebabkan suara menggema dan menimbulkan kesan berisik, namun menurut $\mathrm{A}$ event tersebut adalah daya tarik tersendiri yang diberikan pada pelanggan oleh Ramayana. Selain itu event tersebut juga tidak setiap saat diadakan, hanya di jam tertentu saja. Sebelumnya pihak manajemen sempat mengikuti saran pelanggan untuk tidak melakukan event tersebut, akan tetapi omset penjualan malah menurun sehingga solusi tersebut dinilai tidak efektif untuk penjualan Ramayana Department Store Denpasar.

Menurut K walaupun terdapat beberapa permasalahan dalam lingkungan kerja yang mengganggu, ia telah bekerja selama kurang lebih 10 tahun di perusahaan tersebut dan menyatakan bahwa dirinya sudah nyaman bekerja disana. Selain itu, pihak manajemen Ramayana juga mengimplementasikan sistem rewarding pada wiraniaganya. Sistem ini digunakan untuk memancing wiraniaga yang bekerja di Ramayana Department Store agar berusaha mencapai target penjualan yang diberikan untuk mendapat hadiah. Hadiah yang diberikan oleh Ramayana dapat berupa uang maupun non-uang.

Berdasarkan paparan kasus yang dialami oleh wiraniaga Ramayana Department Store Denpasar, lingkungan kerja yang kurang baik dapat menimbukan pengalaman yang kurang menyenangkan, sehingga kepuasan kerjanya menurun. Pendapat tersebut diperkuat oleh pernyataan Osborn (dikutip dalam Suwatno, 2014: 263) yang menyatakan bahwa kepuasan kerja merupakan derajat positif atau negatifnya perasaan seseorang mengenai berbagai tugas dalam pekerjaan, tempat kerja dan hubungan dengan sesama pekerja. Apabila kepuasan kerja yang didapatkan rendah, maka pekerja akan merasa kurang bersemangat saat bekerja. Menurut G. Terri (dikutip dalam Suwatno, 2014: 268) seorang pekerja akan bekerja dengan penuh semangat apabila kepuasan yang diperoleh tinggi dan pekerjaan yang dilakukan sesuai dengan yang diinginkan pekerja.

Lingkungan kerja dapat dikategorikan menjadi faktor fisik seperti faktor cahaya, suara, sirkulasi udara, penggunaan warna, suhu dan keamanan kerja serta faktor non-fisik yang berupa segala keadaan yang terjadi yang berkaitan dengan hubungan kerja, baik hubungan dengan atasan maupun hubungan sesama rekan kerja, ataupun hubungan dengan bawahan (Sedarmayanti, 2001). Mayoritas karyawan lebih menyukai lingkungan kerja yang bersih, nyaman dan didukung dengan fasilitas yang memadai (Robbins, 2001).

Menurut Locke (dikutip dalam Wijono, 2012) kepuasan kerja merupakan perasaan yang menyenangkan, yang berasal dari persepsi individu dalam rangka menyelesaikan tugas yang diberikan atau untuk memenuhi kebutuhan dalam rangka memeroleh nilai kerja yang penting baginya. Locke (dikutip dalam Wijono, 2012) kemudian mendefinisikan kepuasan kerja sebagai perkiraan individu terhadap pekerjaan atau pengalaman positif pada diri individu. Munandar (2001) menyatakan beberapa faktor yang berpengaruh terhadap kepuasan kerja karyawan yaitu ciri intrinsik pekerjaan, imbalan atau gaji yang diberikan oleh perusahaan, supervisi atau penyeliaan, rekan sejawat yang menunjang dan kondisi kerja yang menunjang.

Wibowo, Musadieq, dan Nurtjahjono (2014) mendapatkan hasil bahwa hubungan antara lingkungan kerja dan kepuasan kerja termasuk hubungan yang kuat yang dibuktikan dengan koefisien korelasi sebesar 0,728. Selain itu, Wibowo, dkk. (2014) juga menemukan bahwa arah hubungan antara keduanya adalah positif sehingga peningkatan pada lingkungan kerja akan menyebabkan peningkatan pada kepuasan kerja. Lingkungan kerja yang mendukung juga menyebabkan terpenuhinya kebutuhan dalam motivasi kerja seperti kebutuhan afiliasi yang berhubungan dengan rekan kerja yang mendukung dan kebutuhan keamanan yang berhubungan dengan keamanan kerja yang baik.

Lingkungan kerja yang baik dapat meningkatkan kinerja karyawan di Department Store. Pendapat tersebut didukung 
oleh penelitian yang dilakukan oleh Nilawati (2017) terkait hubungan lingkungan kerja dengan kinerja karyawan PT. Matahari Department Store Tbk. Kediri. Penelitian tersebut menyimpulkan bahwa variabel lingkungan kerja berpengaruh signifikan terhadap kinerja karyawan Matahari Department Store. Kinerja yang meningkat kemudian dapat mempengaruhi kepuasan kerja yang didapat oleh karyawan (Munandar, 2012).

Porter dan Lawler (dikutip dalam Munandar, 2012) menemukan hubungan timbal balik antara motivasi kerja, kinerja dan kepuasan kerja. Motivasi, kemampuan, dan persepsi menghasilkan kinerja dan memperoleh imbalan. Besarnya imbalan yang diterima akan menentukan besarnya kepuasan kerja. Nilai dari imbalan dan kemungkinan untuk mendapatkan lebih dengan usaha tertentu menentukan motivasi. Berdasarkan penjelasan model Porter dan Lawler (dikutip dalam Munandar, 2012) maka kepuasan kerja menentukan tinggi rendahnya motivasi, kemudian motivasi menghasilkan kinerja yang menentukan kepuasan kerja sehingga terjadi hubungan timbal balik.

Luthans (dikutip dalam Suwatno, 2014) menyatakan terdapat beberapa motivasi kerja yang dimiliki individu yaitu kebutuhan kekuasaan, kebutuhan berprestasi, kebutuhan untuk berhubungan, kebutuhan keamanan dan kebutuhan akan status. Motivasi kerja merupakan aspek penting untuk mencapai kinerja yang tinggi. Pernyataan tersebut dibuktikan dengan penelitian Maharlin (2013) yang meneliti mengenai pengaruh motivasi kerja terhadap kinerja kerja karyawan Robinson Supermarket Samarinda. Penelitian Maharlin (2013) menemukan bahwa variabel motivasi kerja memiliki hubungan yang kuat dengan kinerja.

Menurut Lucas (1994), wiraniaga merupakan karyawan retail yang bertugas untuk memfasilitasi penjualan. Tugas wiraniaga adalah membantu konsumen dari tahap pencarian, pemilihan barang, hingga transaksi pembelian barang tersebut. Peningkatan kinerja terhadap karyawan Department Store khususnya pada wiraniaga dapat memberikan kepuasan terhadap pelanggan. Pernyataan tersebut dibuktikan oleh penelitian Karla (2015) yang membuktikan bahwa aspek pelayanan seperti reliability, assurance, empathy, dan tangible berpengaruh terhadap kepuasan pelanggan. Yohana (2015) dalam artikelnya menyatakan bahwa dengan meningkatkan kepuasan pelanggan, maka keuntungan juga akan meningkat karena pelanggan akan semakin sering membeli produk, dalam jumlah yang lebih banyak, dan cenderung untuk mencoba produk yang ditawarkan oleh perusahaan sehingga menurunkan biaya yang diperlukan untuk pemasaran. Chandra (2002) menyatakan bahwa peningkatan kinerja wiraniaga menjadi penting, karena wiraniaga itu sendiri yang menjadi citra dan ujung tombak perusahaan.

Persepsi merupakan salah satu faktor penentu kepuasan kerja yang dihasilkan secara berbeda antara satu tenaga kerja dengan yang lainnya, dimana para pekerja tersebut mengasosiasikan persepsi tersebut dengan aspek di dalam diri maupun diluar dirinya. Dengan kata lain, persepsi karyawan terhadap lingkungan kerja diasosiasikan bersamaan dengan faktor internal tenaga kerja sehingga memungkinkan penurunan atau peningkatan pada kepuasan kerja yang didapat oleh tenaga kerja tersebut. Dalam hubungan tersebut, motivasi kerja juga dapat berkontribusi terhadap penurunan atau peningkatan kepuasan kerja serta berhubungan dengan persepsi terhadap lingkungan kerja

Berdasarkan paparan di atas, maka peneliti menjadi tertarik untuk melakukan penelitian terhadap pengaruh lingkungan kerja terhadap kepuasan kerja yang dimoderasi motivasi kerja pada wiraniaga Ramayana Department Store. Lingkungan kerja yang mendukung karyawan penting untuk diberikan perhatian, karena dapat memberikan pemenuhan kebutuhan individu, sehingga apabila terpenuhi dengan baik akan menimbulkan persepsi positif dari karyawan yang menyebabkan peningkatan kinerja, mengurangi efek negatif seperti kelelahan, atau ketidakhadiran bahkan keinginan untuk keluar dari pekerjaannya serta hal-hal lain yang tidak diinginkan perusahaan.

\section{METODE PENELITIAN}

\section{Variabel dan Definisi Operasional}

Variabel penelitian diartikan sebagai atribut, atau objek yang mempunyai variasi (Sugiyono, 2012). Beberapa jenis variabel penelitian yang digunakan dalam penelitian ini adalah : pertama, variabel bebas merupakan variabel stimulus yang mempengaruhi dan menjadi sebab perubahan variabel dependen (Sugiyono, 2012). Variabel bebas yang digunakan dalam penelitian ini adalah persepsi terhadap lingkungan kerja. Kotler (2000) mendefinisikan persepsi sebagai proses dimana individu menyeleksi, mengatur, menginterpretasi informasi yang diterima untuk membangun gambaran keseluruhan dari sekumpulan informasi tersebut. Rivai (2006) mengatakan bahwa lingkungan kerja adalah keseluruhan sarana dan prasarana yang ada di sekitar karyawan yang sedang melakukan pekerjaan itu sendiri.

Robbins (2003) mendefiniskan persepsi dengan mengaitkannya terhadap lingkungan, dimana persepsi merupakan proses dimana individu-individu mengorganisasikan dan menafsirkan kesan indera mereka agar memberi makna kepada lingkungan mereka. Ia kemudian mendefinisikan lingkungan kerja sebagai segala sesuatu yang ada di sekitar para pekerja dan yang dapat mempengaruhi dalam menjalankan tugas-tugas yang dibebankan. Berdasarkan definisi yang telah disebutkan, maka persepsi terhadap lingkungan kerja adalah proses seleksi, interpretasi stimulus yang diintegrasikan dengan pengalaman pribadi untuk menciptakan gambaran keseluruhan terhadap segala sesuatu di lingkungan sekitar.

Kedua, variabel tergantung disebut juga sebagai variabel output yang dipengaruhi atau menjadi akibat dari adanya variabel bebas (Sugiyono, 2012). Variabel tergantung yang digunakan dalam penelitian ini adalah kepuasan kerja. Menurut Wijono (2012) kepuasan kerja adalah suatu perasaan menyenangkan, merupakan hasil dari persepsi individu dalam rangka menyelesaikan tugas atau memenuhi kebutuhannya untuk memperoleh nilai-nilai kerja yang penting bagi dirinya. 


\section{HUBUNGAN PERSEPSI TERHADAP LINGKUNGAN KERJA}

Howell dan Dipboye (dikutip dalam Munandar, 2001) mendefinisikan kepuasan kerja sebagai hasil keseluruhan dari derajat rasa suka atau tidak sukanya tenaga kerja terhadap berbagai aspek dari pekerjaannya. Suwatno (2014) mengungkapkan bahwa kepuasan kerja merupakan cara individu merasakan pekerjaan yang berasal dari sikap individu terhadap aspek-aspek dalam pekerjaannya yang dipengaruhi oleh nilai serta karakteristik di dalam dan luar situasi lingkungan pekerjaannya.

Ketiga, variabel moderasi disebut juga variabel bebas kedua, merupakan variabel yang dapat memerkuat atau memerlemah hubungan antara kedua variabel bebas dan tergantung (Sugiyono, 2012). Variabel moderasi yang digunakan dalam penelitian ini adalah motivasi kerja. Menurut Munandar (2001) motivasi adalah suatu proses dimana kebutuhankebutuhan mendorong sesorang untuk melakukan serangkaian proses atau kegiatan yang mengarah kepada tercapainya suatu tujuan yang dimiliki individu. Lawler (dikutip dalam Wijono, 2012) mengartikan motivasi sebagai perilaku yang dikontrol oleh pengontrolan pusat manusia yang mengarahkan individu untuk mencapai sesuatu tujuan. Kanfer, Chen, dan Pritchard (2008) mengungkapkan bahwa motivasi kerja merupakan proses psikologis yang memberikan pengaruh terhadap usaha, intensitas, ketekunan, dan penggunaan sumber yang dimilikinya untuk melakukan aksi di tempat kerja.

\section{Populasi dan Sampel Penelitian}

Peneliti menentukan terlebih dahulu populasi, dimana definisi populasi adalah wilayah generalisasi yang terdiri dari subjek ataupun objek dengan suatu kualitas serta karakteristik tertentu yang ditetapkan oleh peneliti (Sugiyono, 2012). Populasi yang ingin diteliti adalah wiraniaga yang bekerja di toko modern kota madya Denpasar. Populasi yang digunakan dalam penelitian ini adalah wiraniaga yang memliki ciri-ciri atau karakteristik (a) laki-laki dan perempuan dengan pengalaman kerja indoor (dalam ruangan). Alasan peneliti memilih lakilaki dan perempuan sebagai subjek adalah untuk memeroleh karakteristik yang mewakili perusahaan, karena apabila menggunakan salah satu jenis kelamin sebagai data penelitian tidak akan mewakili karakteristik karyawan perusahaan sepenuhnya.

(b) Wiraniaga dengan status karyawan tetap, minimal 1 tahun di tempat kerjanya saat ini. Alasan peneliti memilih status karyawan tetap dengan masa kerja minimal 1 tahun karena karyawan tetap memiliki jam kerja dan tugas yang konsisten sehingga pengaruh terhadap kepuasan kerjanya menjadi optimal. Kondisi karyawan tetap berbeda dengan karyawan yang masih dalam masa magang karena tugas dan tanggung jawabnya lebih besar.

Berdasarkan populasi yang akan diteliti, peneliti menggunakan teknik cluster sampling. Cluster sampling merupakan teknik sampling yang memilih secara acak rumpun atau cluster dari populasi yang telah ditetapkan (Hadi, 1991). Rumpun atau cluster yang digunakan adalah ragam toko modern yang ada di kotamadya Denpasar. Jumlah sampel dapat ditentukan berdasarkan jumlah populasi yang telah diketahui dengan rumus dari Slovin (Sevilla et. al., 2007).

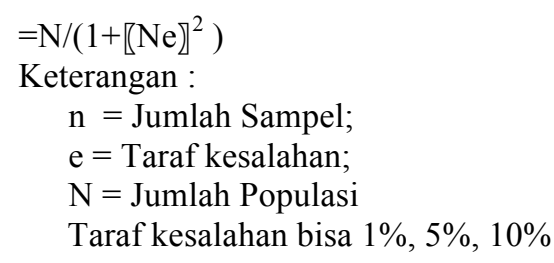

Jumlah wiraniaga yang bekerja diRamayana Department Store diketahui sebesar 68 orang wiraniaga. Berdasarkan perhitungan rumus Slovin (Sevilla et. al., 2007) jumlah sampel yang ditentukan oleh peneliti adalah sebesar 41 orang wiraniaga dengan menggunakan taraf kesalahan $10 \%$.

\section{Metode Pengumpulan Data}

Metode pengumpulan data yang digunakan oleh peneliti adalah skala pengukuran, yang mengacu pada pengukuran aspek atau indikator variabel, yang lebih memudahkan untuk mengetahui pendapat responden lebih mendalam (Azwar, 2010). Teori telah dirangkumkan menjadi beberapa indikator yang kemudian digunakan oleh peneliti sebagai indikator skala untuk pengukuran dengan menggunakan Skala Likert. Skala pengukuran menggunakan jenis data interval yang berisi pernyataan favorable dan unfavorable dengan poin mulai dari 1 hingga 5. Nilai yang diberikan pada pernyataan favorable adalah : Sangat tidak setuju (STS) $=1$ poin, tidak setuju (TS) $=2$ poin, tidak pasti $(\mathrm{TP})=3$ poin, Setuju $(\mathrm{S})=4$ poin, dan Sangat Setuju $(\mathrm{SS})=5$ poin. Sedangkan untuk pernyataan unfavorable adalah sebaliknya : $\mathrm{STS}=5$ poin, $\mathrm{TS}=4$ poin, $\mathrm{TP}$ $=3$ poin, $\mathrm{S}=2$ poin, dan $\mathrm{SS}=1$ poin.

Skala pengukuran yang digunakan oleh peneliti yaitu: pertama, skala persepsi terhadap lingkungan kerja yang dibuat sendiri oleh peneliti. Skala ini menggunakan dimensi yang diungkapkan Sedarmayanti (2001) yaitu penerangan, suhu, suara bising, penggunaan warna, sirkulasi udara, keamanan kerja, dan hubungan karyawan. Skala persepsi terhadap lingkungan kerja memiliki jumlah 31 aitem dengan nilai reliabilitas $(\alpha)$ sebesar 0,917 dan koefisien korelasi yang bergerak dari 0,250 hingga 0,789 .

Kedua, skala kepuasan kerja yang mengadopsi angket Brayfield dan Rothe (dikutip dalam Wijono, 2012). Skala ini menggunakan dimensi yang diungkapkan Munandar (2001) yaitu kompensasi, supervisi, ciri intrinsik pekerjaan, kondisi yang menunjang, dan rekan kerja yang menunjang. Skala kepuasan kerja memiliki jumlah 30 aitem dengan nilai reliabilitas $(\alpha)$ sebesar 0,922 dan koefisien korelasi yang bergerak dari 0,274 hingga 0,860

Ketiga, skala motivasi kerja yang dibuat sendiri oleh peneliti. Skala ini menggunakan dimensi yang diungkapkan oleh Luthans (dikutip dalam Suwatno, 2014) yaitu kebutuhan berprestasi, kebutuhan kekuasaan, kebutuhan berhubungan, kebutuhan keamanan dan kebutuhan status. Skala motivasi kerja memiliki jumlah 19 aitem dengan nilai reliabilitas $(\alpha)$ sebesar 0,860 dan koefisien korelasi yang bergerak dari 0,312 hingga 0,661 . 
Setelah melakukan uji coba terhadap alat ukur penelitian, peneliti menyerahkan surat permohonan ijin pengambilan data pada tanggal 2 November 2016 kepada pihak manajemen Ramayana Department Store. Permohonan ijin tersebut disetujui pada tanggal 9 November 2016 yang diinformasikan secara lisan oleh store manager Ramayana kepada peneliti. Penelitian dilaksanakan pada tanggal 9 November hingga 20 Desember 2016 di Ramayana Department Store yang terletak di jalan Diponegoro Denpasar. Peneliti menyerahkan skala penelitian sebanyak 50 eksemplar kepada salah satu personel perusahaan, yang kemudian dibagikan kepada wiraniaga dengan kriteria yang telah ditentukan peneliti di perusahaan tersebut. Setelah dilakukan pemeriksaan skala yang telah terisi, didapatkan 46 skala yang memenuhi kelengkapan isian. Dengan demikian, maka jumlah responden yang didapatkan dalam penelitian ini adalah sebanyak 46 orang wiraniaga.

\section{Metode Analisis Data}

Analisis data dilakukan dengan bantuan software SPSS (Statistical Package for Social Science) 20 dengan menggunakan analisis Moderated Regression Analysis (MRA). Peneliti menggunakan regresi karena bermanfaat dapat mengetahui hubungan antara kedua variabel yang diteliti sekaligus dapat digunakan untuk memprediksi apakah perubahan yang dilakukan terhadap variabel independen akan berpengaruh terhadap variabel dependen (Sugiyono, 2012). Analisis regresi dengan moderasi digunakan dengan tujuan untuk menganalisis apakah kehadiran variabel moderasi berpengaruh terhadap hubungan antara variabel bebas dan tergantung (Sarwono, 2013).

Uji normalitas data sampel menggunakan teknik uji Shapiro Wilk. Persebaran data sampel dapat dikatakan normal apabila memiliki nilai signifikansi atau probabilitas lebih dari $0,05(\mathrm{p}$ $>0,05)$. Apabila nilai signifikansi dari data sampel kurang dari $0,05(\mathrm{p}<0,05)$ maka data tersebut memiliki distribusi tidak normal. Uji linearitas dalam penelitian ini menggunakan Uji Ramsey Test dengan bantuan program IBM SPSS Statistic 20 for Windows. Uji Ramsey Test bertujuan untuk mencari F hitung, dengan melihat nilai koefisien determinasi (R2) kemudian dibandingkan dengan $\mathrm{F}$ tabel (Ghozali, 2005).

\section{Hipotesis Penelitian}

Uji Hipotesis menggunakan taraf signifikansi 5\% atau 0,05 dan dilakukan dengan melihat koefisien probabilitas. Jika nilai probabilitas berada di bawah $0,05(\mathrm{p}<0,05)$, maka $\mathrm{H} 0$ ditolak yang artinya variabel bebas dan tergantung memiliki hubungan yang siginifikan. Sebaliknya jika nilai probabilitas di atas $0,05(\mathrm{p}>0,05)$, maka H0 diterima yang artinya variabel bebas dan tergantung tidak memiliki hubungan yang signifikan (Sugiyono,2012). Berdasarkan uraian teoritis di atas, maka dapat diajukan hipotesis sebagai berikut.

\section{Hipotesis Nol}

H0 : Tidak terdapat hubungan persepsi terhadap lingkungan kerja dengan kepuasan kerja yang dimoderasi oleh motivasi kerja.

Hipotesis Alternatif
Ha : Terdapat hubungan persepsi terhadap lingkungan kerja dengan kepuasan kerja yang dimoderasi oleh motivasi kerja.

\section{HASIL PENELITIAN}

Analisis data menggunakan uji Moderated Regression Analysis (MRA), namun sebelumnya perlu dilakukan uji normalitas, linieritas dan multikolinieritas. Uji normalitas berfungsi untuk mengetahui sebaran data penelitian, apakah data sampel tersebut memiliki distribusi normal atau tidak. Pada penelitian ini, uji normalitas data sampel menggunakan teknik uji Shapiro Wilk. Persebaran data sampel dapat dikatakan normal apabila memiliki nilai signifikansi atau probabilitas lebih dari $0,05(\mathrm{p}>0,05)$. Apabila nilai signifikansi dari data sampel kurang dari $0,05(\mathrm{p}<0,05)$ maka data tersebut memiliki distribusi tidak normal. (Tabel 1 . Terlampir).

Hasil pada tabel 1 menunjukkan bahwa persebaran atau distribusi data pada ketiga variabel penelitian adalah normal berdasarkan nilai signifikansi dari uji Shapiro Wilk. Hal ini dikarenakan signifikansi atau probabilitas dari hasil uji normalitas ketiga variabel tersebut berada diatas 0,05 ( $\mathrm{p}>$ 0,05) sehingga dapat disimpulkan bahwa sebaran data pada variabel-variabel di atas bersifat normal.

Uji Linearitas bertujuan untuk mengetahui apakah variabel penelitian memiliki hubungan yang linear atau tidak secara signifikan. Uji linearitas dalam penelitian ini menggunakan Uji ramsey test dengan bantuan program IBM SPSS Statistic 20 for Windows. Uji ramsey test bertujuan untuk mencari $\mathrm{F}$ hitung, dengan melihat nilai koefisien determinasi (R2) kemudian dibandingkan dengan $\mathrm{F}$ tabel (Ghozali, 2005). Apabila F hitung lebih kecil dari F tabel maka data yang diuji adalah linier. Adapun rumus untuk mencari $\mathrm{F}$ hitung adalah sebagai berikut.

$$
\begin{aligned}
& \text { Keterangan : } \\
& \begin{array}{ll}
\mathrm{M} & =\text { Jumlah variabel yang baru masuk } \\
\mathrm{R} 21 & =\text { Koefisien Determinasi lama } \\
\mathrm{n} & =\text { Jumlah data yang diobservasi } \\
\mathrm{R} 22 & =\text { Koefisien Determinasi baru } \\
\mathrm{K} & =\text { Banyaknya parameter dalam persamaan baru }
\end{array}
\end{aligned}
$$

Hasil uji pertama ramsey test dengan menggunakan regresi linier yang menunjukkan koefisien determinasi lama dapat dilihat pada tabel 2 (terlampir).

Didapatkan R2 lama sebesar 0,620 dari 3 variabel. Kemudian digunakan parameter residual untuk pengujian kedua. Hasilnya dapat digambarkan pada tabel 3 (terlampir).

Didapatkan R2 lama sebesar 0,620 dari 3 variabel dengan tambahan parameter residual. Kemudian dilanjutkan dengan perhitungan berdasarkan rumus yang menghasilkan $\mathrm{F}$ hitung dengan nilai 18,46 yang lebih kecil dari $F$ tabel yang memiliki nilai sebesar 56,18 sehingga berdasarkan teori Ghozali (2005) dapat disimpulkan bahwa data yang diuji adalah linier. Perhitungan menggunakan rumus adalah sebagai berikut. 
Didapatkan R2 lama sebesar 0,620 dari 3 variabel dengan tambahan parameter residual. Kemudian dilanjutkan dengan perhitungan berdasarkan rumus yang menghasilkan $\mathrm{F}$ hitung dengan nilai 18,46 yang lebih kecil dari F tabel yang memiliki nilai sebesar 56,18 sehingga berdasarkan teori Ghozali (2005) dapat disimpulkan bahwa data yang diuji adalah linier. Perhitungan menggunakan rumus adalah sebagai berikut.

$$
\mathrm{F}=((0,836-0,620) / 3) /((1-0,836) /(46-4))=0,072 / 0,0039=18,46
$$

Uji Multikolinieritas bertujuan untuk melihat korelasi antar variabel bebas. Regresi dapat dikatakan baik apabila variabel bebas tidak memiliki multikolinieritas. Hal tersebut dapat dipantau melalui nilai VIF (Variance Inflation Factor) dan Tolerance dari hasil analisis uji multikolinieritas. Apabila nilai VIF kurang dari 10 (VIF < 10) dan Tolerance lebih dari 0,1 maka tidak ditemukan adanya multikolinieritas pada variabel bebas yang digunakan. Analisis uji multikolinieritas dilakukan menggunakan program IBM SPSS Statistic 20 for Windows. Hasil analisis multikolinieritas dapat dilihat pada tabel 4 (terlampir).

Berdasarkan tabel 4, ditemukan bahwa variabel persepsi terhadap lingkungan kerja dan motivasi kerja memiliki nilai VIF kurang dari 10 (VIF < 10) sebesar 1,559 dan tolerance lebih dari 0,1 (Tolerance $>0,1$ ) sebesar 0,641 . Hal tersebut membuktikan bahwa tidak ditemukan gejala multikolinieritas pada kedua variabel bebas yang digunakan dalam penelitian ini.

Pengujian hipotesis dilakukan dengan menggunakan metode Moderated Regression Analysis (MRA) yang merupakan salah satu dari dua metode untuk mengidentifikasi ada tidaknya variabel moderator (Ghozali, 2005). Moderated Regression Analysis menggunakan pendekatan analitik yang memertahankan integritas sampel dan memberikan dasar untuk mengontrol pengaruh variabel moderator. Dengan membandingkan tiga persamaan yang didapatkan melalui proses regresi, akan diketahui jenis variabel moderator yang diuji. Menurut Ghozali (2005), ketiga persamaan tersebut yaitu (1) $\mathrm{Yi}=\alpha+\beta 1 \mathrm{Xi}+\varepsilon$; (2) $\mathrm{Yi}=\alpha+\beta 1 \mathrm{Xi}+\beta 2 \mathrm{Zi}+\varepsilon$; (3) $\mathrm{Yi}=\alpha+\beta 1 \mathrm{Xi}+\beta 2 \mathrm{Zi}+\beta 3 \mathrm{Xi} * \mathrm{Zi}+\varepsilon$.

Penentuan jenis variabel moderator menggunakan ketiga persamaan tersebut didasarkan atas tiga ketentuan yaitu (1) jika persamaan 2 dan 3 tidak berbeda signifikan atau $(\beta 3=0$; $\beta 2 \neq 0$ ), maka $Z$ bukan variabel moderator, melainkan sebagai variabel prediktor (independen). (2) Apabila persamaan 1 dan 2 tidak berbeda, namun berbeda dengan persamaan 3 atau ( $\beta 2$ $=0 ; \beta 3 \neq 0$ ), maka $\mathrm{Z}$ merupakan variabel moderator murni (pure moderator). (3) Apabila persamaan 1, 2 dan 3 berbeda satu sama lain atau $(\beta 3 \neq \beta 2 \neq 0)$, maka $Z$ merupakan variabel moderator quasi (semu). Melalui persamaan dan ketentuan pengujian tersebut, maka dilakukan uji Moderated Regression Analysis (MRA) untuk menghasilkan persamaan regresi dengan menggunakan program IBM SPSS Statistics 20 for Windows yang menghasilkan analisis pada tabel 5 (terlampir).

Pada tabel 5, variabel bebas (persepsi terhadap lingkungan kerja) memiliki probabilitas yang signifikan, karena memiliki nilai jauh di bawah 0,05 yaitu 0,00 . Artinya variabel bebas (persepsi terhadap lingkungan kerja) memiliki pengaruh secara individual terhadap kepuasan kerja. Nilai beta $(\beta)$ yang merupakan koefisien regresi pada konstanta $(\alpha)$ memiliki nilai sebesar 19,150 yang berarti jika variabel independen dianggap konstan, maka rata-rata tingkat kepuasan kerja wiraniaga sebesar 19,150. Nilai koefisien regresi pada persepsi terhadap lingkungan kerja sebesar 0,715 yang berarti tingkat variabel tergantung (kepuasan kerja) akan meningkat 0,715 pada setiap kenaikan satu point pada variabel bebasnya (persepsi terhadap lingkungan kerja).

Pada tabel 6 (terlampir), variabel bebas (persepsi terhadap lingkungan kerja) memiliki probabilitas yang signifikan, karena memiliki nilai jauh di bawah 0,05 yaitu 0,00 sedangkan variabel moderator (motivasi kerja) tidak signifkan karena memiliki nilai sebesar 0,089 yang melebihi 0,05. Artinya, hanya persepsi terhadap lingkungan kerja yang memiliki pengaruh secara individual terhadap kepuasan kerja. Nilai beta $(\beta)$ yang merupakan koefisien regresi pada konstanta $(\alpha)$ memiliki nilai sebesar 6,846 yang berarti jika variabel independen dianggap konstan, maka rata-rata tingkat kepuasan kerja wiraniaga sebesar 6,846. Sedangkan nilai koefisien regresi pada persepsi terhadap lingkungan kerja sebesar 0,602 yang berarti setiap peningkatan pada variabel tergantung (kepuasan kerja) sebesar satu point, nilai variabel bebas akan meningkat 0,602 (persepsi terhadap lingkungan kerja).

Pada tabel 7 (terlampir), variabel bebas (persepsi terhadap lingkungan kerja) dan moderator (motivasi kerja) memiliki probabilitas yang tidak signifikan, karena memiliki nilai probabilitas sebesar 0,601 dan 0,454 yang lebih dari 0,05. Begitu juga dengan hasil interaksi variabel bebas dan moderator memiliki nilai probabilitas yang tidak signifikan yaitu sebesar 0,357. Artinya tidak ada pengaruh secara individual dari masing-masing variabel bebas, moderator, dan interaksi variabel bebas dengan moderator terhadap variabel tergantung. Ketiga hasil dalam tabel yang telah dijabarkan di atas dapat dirangkumkan ke dalam tiga persamaan garis regresi yaitu (1) $\mathrm{KK}=19,150+0,715 \mathrm{PLK}$; (2) $\mathrm{KK}=6,846+$ $0,602 \mathrm{PLK}+0,430 \mathrm{MK}$; (3) KK $=129,920-0,788 \mathrm{PLK}-$ 1,889 MK + 0,026 PLKxMK

Dapat dilihat berdasarkan persamaan yang telah didapatkan bahwa hasil sesuai dengan ketentuan ketiga, dimana persamaan pertama, kedua dan ketiga berbeda satu sama lain atau $(\beta 3 \neq \beta 2 \neq 0$ ) yang digambarkan pada persamaan kedua dengan nilai $\beta 2$ sebesar 0,430 dan pada persamaan ketiga dengan nilai $\beta 2$ sebesar $-1,889$ serta nilai $\beta 3$ sebesar 0,026 . Hal ini menandakan bahwa variabel $\mathrm{Z}$ yang diuji merupakan variabel moderator quasi (semu).

Berdasarkan tabel sumbangan efektif variabel persepsi terhadap lingkungan kerja kepada kepuasan kerja (tabel 8. terlampir), nilai koefisien determinasi (r2) yang diperoleh dengan menguadratkan nilai $r(0,770)$ menghasilkan nilai sebesar 0,593. Koefisien determinasi ini menunjukkan seberapa besar peran atau sumbangan yang diberikan variabel bebas kepada variabel tergantung (Sugiyono, 2010). Artinya, variabel persepsi terhadap lingkungan kerja secara mandiri 
memberikan peran sebesar 59,3\% terhadap variabel kepuasan kerja. Sisa persentase sebesar 40,7\% dijelaskan oleh faktor lain yang tidak diteliti dalam penelitian ini. Besaran hubungan yang terjadi dapat dilihat melalui koefisien korelasinya (r) sebesar 0,770 .

Berdasarkan tabel sumbangan efektif variabel persepsi terhadap lingkungan kerja dan motivasi kerja kepada kepuasan kerja (tabel 9. Terlampir), nilai koefisien determinasi (r2) yang diperoleh dengan menguadratkan nilai $r \quad(0,788)$ menghasilkan nilai sebesar 0,620. Koefisien determinasi ini menunjukkan seberapa besar peran atau sumbangan yang diberikan variabel bebas dan moderasi kepada variabel tergantung (Sugiyono, 2010). Artinya, variabel persepsi terhadap lingkungan kerja dan motivasi kerja secara bersamasama memberikan peran sebesar $62 \%$ terhadap variabel kepuasan kerja. persentase sebesar 38\% dijelaskan oleh faktor lain yang tidak diteliti dalam penelitian ini. Besaran hubungan yang terjadi dapat dilihat melalui koefisien korelasinya (r) sebesar 0,788 .

Menurut Ghozali (2005), variabel moderator quasi (semu) adalah variabel moderator yang berhubungan dengan variabel prediktor dan/atau kriterion dan sekaligus berinteraksi dengan variabel prediktor lainnya. Artinya dalam penelitian ini, variabel moderator yaitu motivasi kerja berhubungan dengan variabel persepsi terhadap lingkungan kerja (prediktor) dan/atau variabel kepuasan kerja (kriterion) sekaligus berinteraksi dengan variabel prediktor atau independen lainnya yaitu persepsi terhadap lingkungan kerja. Regresi antara motivasi kerja (moderator) dengan persepsi terhadap lingkungan kerja (prediktor) dapat dilihat pada tabel 10 (terlampir).

Berdasarkan tabel hasil regresi variabel moderator terhadap variabel bebas, nilai probabilitas yang didapatkan sebesar 0,00 jauh di bawah 0,05 sehingga motivasi kerja sebagai variabel moderator secara signifikan memiliki hubungan secara individual terhadap variabel persepsi terhadap lingkungan kerja sebagai variabel bebas.

Setelah dipastikan bahwa variabel motivasi kerja (moderator) memiliki hubungan dengan variabel prediktor, perlu dipastikan juga interaksi antara variabel moderator dan bebas tersebut dalam upayanya memengaruhi variabel independen. Karena itu uji signifikansi simultan yang dapat diperiksa melalui tabel 11 (terlampir).

Berdasarkan tabel uji signifikansi simultan, didapatkan nilai $\mathrm{F}$ hitung sebesar 23,627 dengan probabilitas 0,00. Dikarenakan probabilitas jauh lebih kecil dari 0,05 maka model regresi yang telah dilakukan dapat digunakan untuk memprediksi tingkat kepuasan kerja atau variabel bebas, moderator serta interaksi dari keduanya secara bersama-sama berpengaruh terhadap variabel tergantung.

\section{PEMBAHASAN DAN KESIMPULAN}

Hasil uji hipotesa penelitian ini adalah terdapat hubungan persepsi terhadap lingkungan kerja terhadap kepuasan kerja yang dimoderasi motivasi kerja pada wiraniaga perusahaan di Ramayana Department Store Denpasar. Artinya hipotesa alternatif (Ha) penelitian ini diterima, dimana motivasi kerja sebagai variabel pemoderasi berperan dalam menguatkan atau melemahkan nilai kepuasan kerja pada wiraniaga Ramayana Department Store. Jenis moderasi yang dihasilkan oleh motivasi kerja dapat dilihat melalui hasil analisis hipotesis dengan menggunakan Moderated Regression Analysis (MRA).

Berdasarkan uji signifikansi parameter individual pada persamaan kedua uji MRA, hanya variabel bebas yaitu persepsi terhadap lingkungan kerja yang memiliki nilai probabilitas yang signifikan sebesar 0,00 sedangkan variabel pemoderasi memiliki nilai probabilitas sebesar 0,089 yang lebih dari 0,05 . Berarti hanya persepsi terhadap lingkungan kerja yang memiliki hubungan sebab akibat terhadap kepuasan kerja, sedangkan motivasi kerja tidak memiliki hubungan sebab akibat tersebut.

Persepsi terhadap lingkungan kerja yang memiliki hubungan signifikan dengan kepuasan kerja terbukti sesuai dengan teori 3 komponen kepuasan kerja oleh Wijono (2012) karena kepuasan didasarkan pada persepsi individu terhadap situasi dan nilai individu. Persepsi yang berkaitan dengan kepuasan kerja dalam penelitian ini difokuskan pada lingkungan kerja yaitu rekan kerja dan kondisi kerja yang menunjang seperti yang diungkapkan Munandar (2001).

Persepsi terhadap lingkungan kerja yang dibangun dalam diri individu merupakan kumpulan pengalaman yang telah dibandingkan dengan apa yang diharapkan olehnya. Hal tersebut sesuai dengan ungkapan oleh Locke dalam Suwatno (2014) bahwa kepuasan kerja seseorang tergantung pada discrepancy antara harapan, kebutuhan serta nilai yang berkaitan langsung dengan aspek perasaan serta persepsi yang dihasilkan atau diperoleh individu dalam pekerjaannya. Motivasi dapat digambarkan sebagai harapan yang perlu dicapai.

Dalam upaya pencapaiannya individu menyesuaikan diri dengan kenyataan yang ada. Kemudian individu akan membentuk sebuah persepsi terhadap lingkungannya, dimana harapan yang dijadikan motivasi dibandingkan dengan pencapaian dan pemenuhan kebutuhan tersebut dalam kenyataan sehingga akan memengaruhi kepuasan kerjanya. Artinya, motivasi kerja harus berinteraksi dengan persepsi terhadap lingkungan kerja untuk dapat meningkatkan atau menurunkan kepuasan kerja.

Arah hubungan antara persepsi terhadap lingkungan kerja kepada kepuasan kerja dapat dilihat melalui nilai koeifisien beta $(\beta)$ pada persamaan regresi kedua sebesar 0,602 yang berarti hubungannya searah karena nilainya positif. Hubungan tersebut dapat diyakini sebagai gejala sebab akibat dan bukan merupakan gejala random karena dapat meramalkan apabila terjadi kenaikan nilai sebesar satu point pada variabel kepuasan kerja, maka nilai persepi terhadap lingkungan kerja akan meningkat sebesar 0,602 atau juga sebaliknya apabila nilai persepsi terhadap lingkungan kerja meningkat sebesar 0,602 maka nilai kepuasan kerja akan meningkat sebesar satu point.

Motivasi kerja memiliki nilai probabilitas yang tidak 
siginifikan terhadap kepuasan kerja yaitu sebesar 0,089 (tabel 6) pada persamaan regresi kedua, maka dari itu dapat disimpulkan bahwa arah hubungannya tidak memiliki hubungan langsung namun bersama-sama dengan persepsi terhadap lingkungan kerja sehingga total nilai koefisien betanya sebesar $(0,602+0,430)$ 1,032. Artinya interaksi antara persepsi terhadap lingkungan kerja dengan motivasi kerja menghasilkan arah hubungan yang searah dan setiap kenaikan nilai kepuasan kerja sebesar satu point akan meningkatkan total nilai persepsi terhadap lingkungan kerja dan motivasi kerja sebesar 1,032. Begitu pula sebaliknya apabila total nilai persepsi terhadap lingkungan kerja dan motivasi kerja meningkat sebesar 1,032 maka nilai kepuasan kerja juga akan meningkat sebesar satu point. Terbukti mengapa responden dalam ketiga variabel penelitian memiliki tingkatan yang tinggi, disebabkan oleh hubungan yang searah.

Dari uji variabel moderator, hasil moderasi yang mungkin terjadi dapat dibedakan menjadi empat yaitu variabel prediktor biasa, variabel moderator homologizer, moderator quasi (semu) dan moderator pure (murni). Pengelompokan ini didasarkan pada dua hal, hubungan variabel moderasi dengan variabel bebas dan tergantung, serta interaksi moderator dengan variabel bebas. Apabila moderator tidak berinteraksi dengan variabel bebasnya, maka hasil yang mungkin didapatkan adalah variabel prediktor biasa atau homologizer. Sebaliknya jika terdapat interaksi, maka hasil yang mungkin didapatkan adalah variabel moderasi semu atau murni (Ghozali, 2005).

Motivasi kerja dibuktikan sebagai variabel pemoderasi quasi (semu) melalui hasil uji Moderated Regression Analysis (MRA). Ghozali (2005) menyatakan bahwa variabel moderasi quasi atau semu adalah jenis variabel yang memodifikasi bentuk hubungan antara variabel bebas dan tergantung. Variabel yang dapat dikatakan moderasi semu adalah moderator yang berhubungan dengan variabel bebas dan/atau variabel tergantung sekaligus berinteraksi dengan variabel bebas. Dalam penelitian ini, motivasi kerja berhubungan dan berinteraksi dengan persepsi terhadap lingkungan kerja sehingga memodifikasi hubungan terhadap kepuasan kerja.

Variabel motivasi kerja dapat menguatkan atau melemahkan tingkat kepuasan kerja wiraniaga Ramayana Department Store Denpasar hanya apabila berinteraksi dengan variabel persepsi terhadap lingkungan kerja. Hal ini dibuktikan melalui uji MRA dengan kesesuaian syarat dimana persamaan pertama, kedua dan ketiga berbeda satu sama lain atau $(\beta 3 \neq \beta 2 \neq 0)$ yang digambarkan pada persamaan kedua dengan nilai $\beta 2$ sebesar 0,430 dan pada persamaan ketiga dengan nilai $\beta 2$ sebesar $-1,889$ serta nilai $\beta 3$ sebesar 0,026 sehingga motivasi kerja merupakan variabel moderator quasi.

Berdasarkan uji signifikansi simultan didapatkan nilai $\mathrm{F}$ hitung sebesar 23,627 dengan probabilitas 0,00. Dikarenakan probabilitas jauh lebih kecil dari 0,05 maka model regresi yang telah dilakukan dapat digunakan dan dipercaya untuk meramalkan kontribusi persepsi terhadap lingkungan kerja dan motivasi kerja dalam memrediksi tingkat kepuasan kerja atau dapat dikatakan bahwa interaksi dari persepsi terhadap lingkungan kerja dan motivasi kerja secara bersama-sama berpengaruh secara signifikan terhadap kepuasan kerja.
Besaran sumbangan persepsi terhadap lingkungan kerja kepada kepuasan kerja didapatkan melalui nilai koefisien determinasi ( $\mathrm{r} 2$ ) yang diperoleh dengan menguadratkan nilai $\mathrm{r}$ $(0,770)$ menghasilkan nilai sebesar 0,593 atau memiliki persentase $59,3 \%$, sisanya yaitu $40,7 \%$ dijelaskan oleh faktor lain diluar penelitian ini. Sedangkan besarnya sumbangan atau peran persepsi terhadap lingkungan kerja dan motivasi kerja kepada kepuasan kerja didapatkan melalui nilai koefisien determinasi (r2) dengan menguadratkan nilai $r \quad(0,788)$ menghasilkan nilai sebesar 0,620 yang berarti sumbangan yang dihasilkan oleh variabel bebas dan moderasi dalam persentase adalah sebesar $62 \%$, sisanya yaitu $38 \%$ dijelaskan oleh faktor lain diluar penelitian ini. Terbukti bahwa sumbangan efektif variabel persepsi terhadap lingkungan kerja akan meningkat kepada kepuasan kerja apabila berinteraksi dengan motivasi kerja sebagai variabel pemoderasi.

Motivasi kerja berinteraksi dengan persepsi terhadap lingkungan kerja sehingga memengaruhi tingkat kepuasan kerja yang diukur. Motivasi kerja juga berhubungan dengan persepsi terhadap lingkungan kerja. Saat dipasangkan keduanya dalam mengukur kepuasan kerja, besaran sumbangan efektif yang didapatkan meningkat, namun secara mandiri motivasi kerja tidak berhubungan dengan kepuasan kerja. Jadi, motivasi kerja terlihat seakan berhubungan dengan kepuasan kerja saat dipasangkan dengan persepsi terhadap lingkungan kerja, padahal ini disebabkan oleh interaksinya dengan variabel bebas. Kanfer, dkk. (2008) mengungkapkan bahwa motivasi kerja merupakan proses psikologis yang memberikan pengaruh terhadap usaha, intensitas, ketekunan, dan penggunaan sumber yang dimilikinya untuk melakukan aksi di tempat kerja. Dengan motivasi kerja yang tinggi, maka wiraniaga Ramayana Department Store akan menghasilkan kinerja yang baik. Hubungan yang terjadi dapat diejlaskan berdasarkan penjelasan model Porter dan Lawler (dikutip dalam Munandar, 2012) yang mengungkapkan bahwa motivasi menghasilkan kinerja yang menentukan kepuasan kerja sehingga terjadi hubungan timbal balik.

Berdasarkan tabel interpretasi koefisien korelasi sugiyono (2014) (tabel 12. Terlampir), nilai koefisien korelasi persepsi terhadap lingkungan kerja dan motivasi kerja kepada kepuasan kerja pada wiraniaga Ramayana Department Store sebesar 0,788 termasuk dalam kategori hubungan yang kuat yaitu pada interval $0,60-0,799$ sedangkan nilai koefisien korelasi persepsi terhadap lingkungan kerja secara mandiri terhadap kepuasan kerja pada wiraniaga Ramayana Department Store sebesar 0,770 juga termasuk dalam kategori hubungan yang kuat.

Berdasarkan hasil analisis dan pembahasan yang telah dijabarkan, maka kesimpulan yang didapatkan dalam penelitian ini adalah terdapat hubungan antara persepsi terhadap lingkungan kerja dengan kepuasan kerja yang dimoderasi dengan motivasi kerja pada wiraniaga Ramayana Department Store. Variabel motivasi kerja tidak berperan langsung dalam meningkatkan atau menurunkan kepuasan kerja, namun secara bersama-sama berinteraksi dengan variabel persepsi terhadap lingkungan kerja sehingga menjadi variabel moderasi semu atau kuasi berperan terhadap variabel bebas kepuasan kerja. Artinya, motivasi kerja berhubungan dengan persepsi terhadap lingkungan kerja, kemudian 
berinteraksi secara simultan untuk meningkatkan peran dari variabel bebas tersebut terhadap kepuasan kerja tanpa memengaruhi variabel tergantung secara individual.

Variabel persepsi terhadap lingkungan kerja secara signifikan memiliki hubungan yang fungsional dengan kepuasan kerja. Apabila terjadi kenaikan nilai sebesar satu point pada variabel kepuasan kerja, maka nilai persepi terhadap lingkungan kerja akan meningkat sebesar 0,602. Peran persepsi terhadap lingkungan kerja pada kepuasan kerja dapat dilihat melalui sumbangan efektifnya yang menghasilkan persentase sebesar $59,3 \%$ sedangkan hasil interaksi dari persepsi terhadap lingkungan kerja dan motivasi kerja menghasilkan sumbangan efektif pada kepuasan kerja dengan Persentase sebesar $62 \%$. Terbukti bahwa interaksi dengan variabel moderasi yaitu motivasi kerja meningkatkan sumbangan efektif yang dihasilkan kepada kepuasan kerja sebagai variabel tergantung. Hubungan berdasarkan interpretasi korelasi antara persepsi terhadap lingkungan kerja dengan kepuasan kerja adalah termasuk dalam kategori hubungan yang kuat. Begitu juga dengan hubungan antara interaksi dari persepsi terhadap lingkungan kerja dan motivasi kerja pada kepuasan kerja juga menimbulkan hubungan yang kuat.

Berdasarkan kesimpulan yang didapatkan dalam penelitian ini, saran diberikan peneliti kepada (1) perusahaan Ramayana Department Store adalah agar perusahaan untuk memertahankan atau meningkatkan lingkungan kerja, baik fisik maupun non-fisik yang sehat dan nyaman bagi wiraniaganya. Lingkungan kerja yang nyaman menyebabkan motivasi kerja wiraniaga meningkat karena terpenuhinya kebutuhan fisiologis, keamanan serta interaksi antar individu, serta tidak ada gangguan yang mengganggu kinerja. Seperti yang dikatakan Kusriyanto (1991) bahwa seseorang yang bekerja di lingkungan kerja yang baik dan mendukung dapat bekerja dengan optimal sehingga kinerja yang baik akan tercipta. Sebaliknya apabila lingkungan kerja kurang mendukung, maka wiraniaga akan menjadi malas dan cepat lelah sehingga kinerja akan menurun. Kesimpulan tersebut didasarkan pada hasil dalam penelitian ini bahwa peningkatan persepsi terhadap lingkungan kerja beserta motivasi kerja akan meningkatkan kepuasan kerja dari tiap wiraniaga.

Motivasi kerja tidak berperan langsung dalam meningkatkan kepuasan kerja wiraniaga, namun motivasi kerja tetap dapat meningkatkan kepuasan kerja secara tidak langsung ketika bersama dengan variabel persepsi terhadap lingkungan kerjanya. Berdasarkan teori Luthans (dikutip dalam Suwatno, 2014) terdapat beberapa hal yang dapat dilakukan perusahaan untuk memberikan dorongan, contohnya memberikan tugas yang menantang untuk kebutuhan prestasi, menciptakan suasana yang kompetitif untuk kebutuhan kekuasaan, dan memberikan jaminan keselamatan kerja yang cukup untuk kebutuhan keamanan.

(2) Saran bagi wiraniaga Ramayana Department Store adalah untuk aktif berkomunikasi kepada perusahaan apabila terdapat kekurangan dari lingkungan kerjanya, karena dapat memengaruhi kepuasan kerjanya. Seperti yang diungkapkan Leavitt (dikutip dalam Wijono, 2012) bahwa menempatkan tenaga kerja ke dalam jalinan komunikasi yang erat dapat menumbuhkan kepuasan kerja yang tinggi pada anggota kelompok sehingga komunikasi yang terjalin menjadi baik dan tercipta hubungan saling memahami. Hubungan tersebut menyebabkan pihak manajemen perusahaan dapat mengambil tindakan yang lebih menguntungkan bagi perusahaan itu sendiri maupun wiraniaganya.

(3) Saran bagi peneliti berikutnya yang tertarik untuk meneliti dengan variabel yang sama dengan penelitian ini, diharapkan lebih teliti pada pemberian, penyajian dan pengisian skala oleh responden. Diharapkan agar skala yang telah diisi oleh responden memiliki data yang kaya dan mencegah banyak skala yang tidak terisi. Disarankan untuk meminta responden mengisi langsung di tempat dan sesudah terisi diperiksa kembali oleh peneliti. Saran tersebut mungkin akan sulit dilakukan karena perusahaan terkadang tidak mengijinkan peneliti untuk menyita waktu kerja karyawannya. Cara lain yang mungkin untuk dilakukan adalah menciptakan komunikasi yang baik dengan pihak perusahaan, dengan tujuan dapat meningkatkan kerja sama dalam upaya pengumpulan data yang lengkap. Komunikasi yang baik antara peneliti dan perusahaan akan memungkinkan skala penelitian terisi dengan data lengkap.

Peneliti berikutnya juga diharapkan mencari hubungan langsung motivasi kerja dengan variabel lainnya. Motivasi kerja dalam penelitian ini dapat berperan namun tidak secara mandiri. Tidak ditemukan adanya hubungan sebab akibat dalam penelitian ini, namun ada pengaruh yang dapat dihasilkan secara tidak langsung. Diperkirakan bahwa terdapat variabel lain yang menjadi perantara antara motivasi kerja dengan kepuasan kerja. Peneliti berharap agar penelitian berikutnya menggali variabel lingkungan kerja lebih dalam dari sudut pandang ergonomi karena melalui sudut pandang manajemen sumber daya manusia (MSDM) hanya didapatkan gambaran subjektif dari responden penelitian saja. Penggunaan ilmu ergonomi akan menghasilkan gambaran yang lebih jelas tentang lingkungan kerja seperti apa yang berperan baik bagi tenaga kerja.

\section{DAFTAR PUSTAKA}

Ashara, L. (2015, December). Perkembangan Industri Ritel di Indonesia. Diunduh dari https://id.linkedin.com/pulse/perkembangan-industri-riteldi-indonesia-larasaty-ashara 15 Agustus 2017

Azwar, S. (2010). Penyusunan skala psikologis. Yogyakarta : Pustaka Pelajar.

Chandra, G. (2002). Strategi dan Program Pemasaran. Yogyakarta: Andi Offset.

Duncan, D. (1951). Retailing : principles and methods 3rd edition. United States of America: Richard D. Irwin, Inc.

Dwijayanto, A. (2017, July). Penjualan Ramayana Terdongkrak Transformasi Usaha. Diunduh dari http://m.kontan.co.id/news/penjualan-ramayanaterdongkrak-transformasi-usaha 18 Agustus 2017

Ghozali, I. (2005). Aplikasi analisis multivariate dengan program SPSS edisi 3. Semarang: Badan Penerbit Universitas Diponegoro.

Ghozali, I. (2005). Aplikasi analisis multivariate dengan program IBM SPSS 20 edisi 6. Semarang: Badan Penerbit Universitas Diponegoro.

Hadi, S. (1991). Statistik 2. Yogyakarta: Andi Offset. 
Kanfer, R., Chen, G., \& Pritchard, R.,D. (2008). Work motivation past, present, and future. New York: Taylor \& Francis Group.

Karla, E. (2015). Analisis pengaruh kualitas pelayanan terhadap kepuasan konsumen pada Matahari Department Store Kramat Jati. UG Jurnal 9(9):1-3.

Kotler, P. (1994). Marketing management: Analysis, planning, implementation and

Control, 8th edition. New Jersey: Prentice Hall International.

Kotler, P. (2000). Marketing management: Analysis, planning, implementation and control 9th edition. New Jersey: Prentice Hall International.

Kusriyanto, B. (1991). Meningkatkan produktvitas karyawan. Jakarta: Pustaka Binaman Pressindo.

Lewinson, D. (1989). Retailing 3rd edition. Columbus: Merrill Publishing Company.

Lucas, Jr George H., Robert P and Graham, Larry G. (1994). Retailing. Boston, Massachusetts: Houghton Mifflin Company.

Luthans, F. (2006). Perilaku organisasi edisi 10. Yogyakarta: Andi.

Maharlin, R. (2013). Pengaruh motivasi kerja terhadap produktivitas kerja karyawan Robinson Supermarket Samarinda. Jurnal Administrasi Bisnis 1(4): 298-314.

Munandar, A., S. (2001). Psikologi industri dan organisasi. Jakarta: Universitas Indonesia Press.

Nilawati, T. (2017). Pengaruh lingkungan kerja, komitmen, dan disiplin kerja terhadap kinerja karyawan pada PT. Matahari Department Store Kediri. Skripsi. Fakultas Ekonomi Universitas Nusantara Persatuan Guru Republik Indonesia. Kediri.

Ramayana. (2017). Company Profile. Diunduh dari http://corporate.ramayana.co.id/index.php/en/about-thecompany 18 Juli 2017

Rema, D. (2013, June). Galeries Lafayette, Department Store Asal Prancis Resmi Dibuka di Indonesia. Diunduh dari https://wolipop.detik.com/read/2013/06/13/135900/227245 3/1140/galeries-lafayette-department-store-asal-prancisresmi-dibuka-di-indonesia 15 Agustus 2017

Rivai, Veithzal. (2006). Manajemen sumber daya manusia untuk perusahaan. Jakarta: Raja Grafindo Persada.

Robbins, S. P. (2001). Psikologi organisasi edisi ke-8. Jakarta: Prenhallindo.

Robbins, S. P. (2003). Perilaku organisasi jilid I. Jakarta: PT INDEKS Kelompok Gramedia.

Sarwono, J. (2013). Statistik multivariate aplikasi untuk riset skripsi. Yogyakarta: Andi Offset.

Sedarmayanti. (2001). Sumber daya manusia dan produktivitas kerja. Bandung: Mandar Maju.

Sugiyono. (2012). Metode penelitian bisnis. Bandung: Alfabeta.

Sugiyono. (2014). Metode penelitian pendidikan (Pendekatan kuantitatif, kualitatif, dan R\&D). Bandung: Alfabeta.

Suwatno, H. (2014). Manajemen SDM dalam organisasi publik dan bisnis. Bandung: Alfabeta.

Wibowo, M., M. Al Musadieq, dan G. Eko Nurtjahjono. (2014). Pengaruh lingkungan kerja terhadap kepuasan kerja karyawan (Studi pada karyawan PT. Telekomunikasi Indonesia Tbk. Kandatel Malang). Jurnal Administrasi Bisnis 16(1): 1-9.

Wijono, S. (2012). Psikologi industri \& organisasi (Dalam suatu bidang gerak psikologi sumber daya manusia) edisi revisi. Jakarta: Kencana Prenada Media Group.

Yohana, K. (2015, October). Pengaruh Kepuasan Pelanggan terhadap Profit Perusahaan. Diunduh dari https://id.linkedin.com/pulse/pengaruh-kepuasanpelanggan-terhadap-profit-consulting-group 10 Juni 2017 
I. P. W. MADE \& SUPRIYADI

Tabel 1

Uji Normalitas Sebaran Data Persepsi terhadap lingkungan kerja, Kepuasan Kerja dan Motivasi Kerja

\begin{tabular}{cccc}
\hline Variabel & Shapiro-Wilk & Sig (p) & Distribusi \\
\hline Persepsi terhadap lingkungan & 0,951 & 0,057 & Normal \\
kerja & & & Normal \\
Kepuasan Kerja & 0,961 & 0,125 & Normal \\
Motivasi Kerja & 0,966 & 0,198 & \\
\hline
\end{tabular}


Tabel 2

Uji Linearitas Variabel Penelitian

\begin{tabular}{llllll}
\multicolumn{7}{c}{ Model Summary } \\
\hline Model & $\mathrm{R}$ & R Square & Adjusted R Square & $\begin{array}{l}\text { Std. } \\
\text { Estimate }\end{array}$ & of the \\
\hline 1 &, $788^{\mathrm{a}}$ &, 620 &, 603 & 3,72031 \\
\hline
\end{tabular}

a. Predictors: (Constant), TotalMK, TotalPLK

b. Dependent Variable: TotalKK 
I. P. W. MADE \& SUPRIYADI

Tabel 3

Uji Linieritas Variabel Penelitian dengan Parameter Residual (DFF)

Model Summary ${ }^{\mathrm{b}}$

\begin{tabular}{ccccc}
\hline Model & $\mathrm{R}$ & R Square & Adjusted R Square & $\begin{array}{c}\text { Std. Error of the } \\
\text { Estimate }\end{array}$ \\
\hline 1 &, $914^{\mathrm{a}}$ &, 836 &, 824 & 2,47747 \\
\hline
\end{tabular}

a. Predictors: (Constant), DFFIT, TotalMK, TotalPLK

b. Dependent Variable: TotalKK 
Tabel 4

Uji Multikolinieritas Antar Variabel

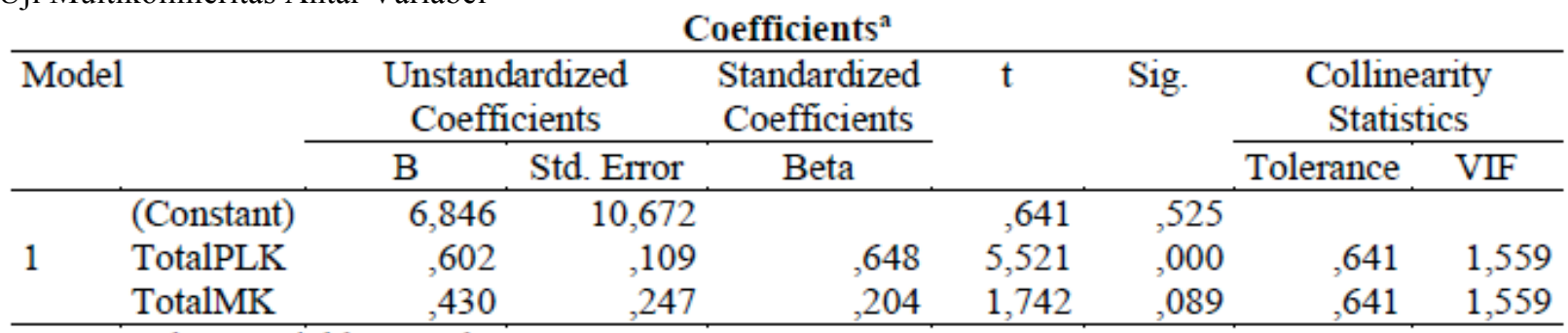

a. Dependent Variable: TotalKK 
I. P. W. MADE \& SUPRIYADI

Tabel 5

Hasil Uji Signifikansi Parameter Individual Persamaan Pertama

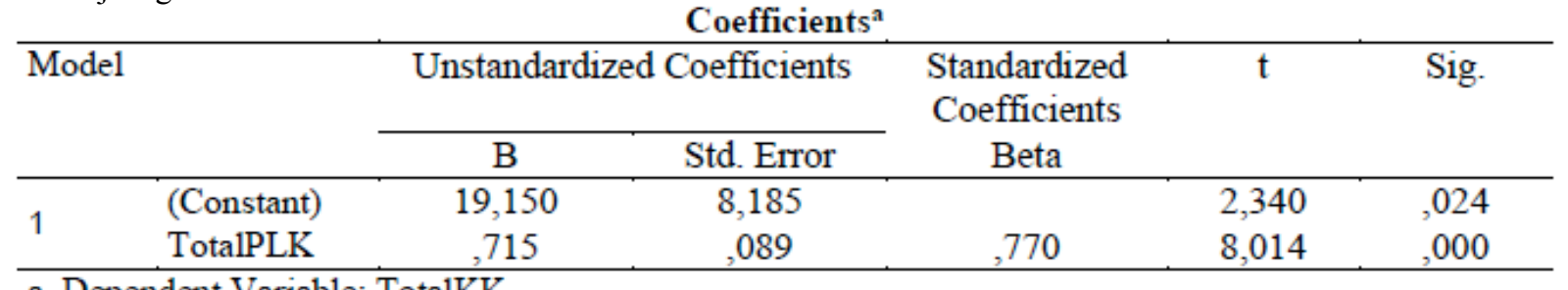

a. Dependent Variable: TotalKK 
Tabel 6

Hasil Uji Signifikansi Parameter Individual Persamaan Kedua

Coefficients $^{\mathrm{a}}$

\begin{tabular}{llccccc}
\hline Model & & \multicolumn{2}{c}{ Unstandardized Coefficients } & $\begin{array}{c}\text { Standardized } \\
\text { Coefficients }\end{array}$ & $\mathrm{t}$ & Sig. \\
\cline { 3 - 5 } & & $\mathrm{B}$ & Std. Error & Beta & & \\
\hline \multirow{2}{*}{1} & (Constant) & 6,846 & 10,672 & &, 641 &, 525 \\
& TotalPLK &, 602 &, 109 &, 648 & 5,521 &, 000 \\
& TotalMK &, 430 &, 247 &, 204 & 1,742 &, 089 \\
\hline
\end{tabular}

a. Dependent Variable: TotalKK 
Tabel 7

Hasil Uji Signifikansi Parameter Individual Persamaan Ketiga

Coefficients $^{\mathrm{a}}$

\begin{tabular}{|c|c|c|c|c|c|c|}
\hline \multirow[t]{2}{*}{ Model } & & \multicolumn{2}{|c|}{ Unstandardized Coefficients } & \multirow{2}{*}{$\begin{array}{c}\begin{array}{c}\text { Standardized } \\
\text { Coefficients }\end{array} \\
\text { Beta }\end{array}$} & \multirow[t]{2}{*}{$t$} & \multirow[t]{2}{*}{ Sig. } \\
\hline & & $\mathrm{B}$ & Std. Error & & & \\
\hline \multirow{4}{*}{1} & (Constant) & 129,920 & 132,538 & & ,980 &, 333 \\
\hline & TotalPLK &,- 788 & 1,496 &,- 849 &,- 527 &, 601 \\
\hline & TotalMK & $-1,889$ & 2,501 &,- 899 &,- 755 &, 454 \\
\hline & PLKXMK &, 026 &, 028 & 2,333 & ,932 & 357 \\
\hline
\end{tabular}

a. Dependent Variable: TotalKK 
Tabel 8

Sumbangan Efektif Persepsi terhadap Lingkungan Kerja kepada Kepuasan Kerja Model Summary

\begin{tabular}{lcrrr}
\hline Model & R & R Square & Adjusted R Square & $\begin{array}{c}\text { Std. Error of the } \\
\text { Estimate }\end{array}$ \\
\hline 1 &, $770^{\mathrm{a}}$ &, 593 &, 584 & 3,80540 \\
\hline a. Predictors: (Constant), TotalPLK & & &
\end{tabular}


I. P. W. MADE \& SUPRIYADI

Tabel 9

Sumbangan Efektif Persepsi terhadap Lingkungan Kerja dan Motivasi Kerja kepada Kepuasan Kerja

\begin{tabular}{lcccc}
\multicolumn{4}{c}{ Model Summary } \\
\hline Model & $\mathrm{R}$ & R Square & Adjusted R Square & $\begin{array}{c}\text { Std. Error of the } \\
\text { Estimate }\end{array}$ \\
\hline 1 &, $788^{\mathrm{a}}$ &, 620 &, 603 & 3,72031 \\
\hline a. Predictors: (Constant), TotalMK, TotalPLK & &
\end{tabular}


Tabel 10

Hasil Uji Regresi Variabel Moderator terhadap Variabel Bebas

\begin{tabular}{|c|c|c|c|c|c|c|}
\hline \multirow[t]{2}{*}{ Model } & & \multicolumn{2}{|c|}{ Unstandardized Coefficients } & \multirow{2}{*}{$\begin{array}{c}\text { Standardized } \\
\text { Coefficients } \\
\text { Beta }\end{array}$} & \multirow[t]{2}{*}{$\mathrm{t}$} & \multirow[t]{2}{*}{ Sig. } \\
\hline & & B & Std. Error & & & \\
\hline \multirow{2}{*}{1} & (Constant) & 19,850 & 14,458 & & 1,373 & 177 \\
\hline & TotalMK & 1,356 &, 273 & ,599 & 4,961 &, 000 \\
\hline
\end{tabular}

a. Dependent Variable: TotalPLK 
I. P. W. MADE \& SUPRIYADI

Tabel 11

Uji Signifikansi Simultan

ANOVA $^{\mathrm{a}}$

\begin{tabular}{llccccc}
\hline Model & & Sum of Squares & df & Mean Square & F & Sig. \\
\hline \multirow{3}{*}{1} & Regression & 984,051 & 3 & 328,017 & 23,627 &, $000^{\mathrm{b}}$ \\
& Residual & 583,101 & 42 & 13,883 & & \\
& Total & 1567,152 & 45 & & & \\
\hline
\end{tabular}

a. Dependent Variable: TotalKK

b. Predictors: (Constant), PLKxMK, TotalMK, TotalPLK 
Tabel 12

Tabel Interpretasi Koefisien Korelasi Sugiyono (2014)

\begin{tabular}{cc}
\hline Interval & Kategori Hubungan \\
\hline $0,00-0,199$ & Sangat Rendah \\
$0,20-0,399$ & Rendah \\
$0,40-0,599$ & Sedang \\
$0,60-0,799$ & Kuat \\
$0,80-1,000$ & Sangat Kuat \\
\hline
\end{tabular}

